\title{
Analisis Framing Pemberitaan Debat Kandidat Calon Presiden Tahun 2019 di Koran Harian Padang Ekspres
}

\author{
Rifa Yanas \\ Pascasarjana FISIP Universitas Andalas \\ rifayanas89@gmail.com
}

\begin{abstract}
Mass media coverage during the general election in 2014 still leaving a portrait that tarnished the principles and code of ethics of journalism in Indonesia. Press companies are considered not neutral and not balanced in reporting the candidates for president and vice president who are fighting in election process. It is also possible that something similar will happen again in 2019 elections. In West Sumatra, Padang Ekspres Daily Newspaper is daily print media that has the biggest circulation and reach many readers. The reality of events surrounding the election campaign, constructed differently by the print media through a framing process. This type of research is qualitative using a constructivist paradigm with William A Gamson's framing analysis model that emphasizes the existence of a central idea in every framing of news by the mass media. The central idea supported by a framing devices consisting of metaphors, catchphrases, exemplar, depiction and visual images. In addition, the central idea is also strengthened by the presence of reasoning devices consisting of roots, appeals to principle and consequences. With this model, the packaging of events that displayed through the framing process by the mass media can be analyzed within a certain range. But it did not come to the conclusion of agreement and disagreement or partiality and impartiality of the mass media to one of the candidates for the election contestants. The conclusion of this study shows that news units studied from the print media as objects of research have various central ideas
\end{abstract}

Keywords: News Framing; 2019 Election Campaign; West Sumatra Print Media

\begin{abstract}
Abstrak
Pemberitaan media massa sepanjang Pemilihan Umum (Pemilu) tahun 2014 meninggalkan potret yang mencoreng prinsip dan kode etik jurnalisme di Indonesia. Perusahaan pers dianggap tidak netral dan tidak berimbang dalam memberitakan calon presiden dan
\end{abstract}

Jurnal Dakwah dan Komunikasi

IAIN Curup | E-ISSN 2548-3366 ; P- ISSN 2548-3293 
wakil presiden yang bertarung dalam proses pemilu. Tidak tertutup kemungkinan hal serupa kembali terjadi di pemilu tahun 2019. Di Sumatra Barat, Harian Padang Ekspresmerupakan media cetak harian yang memiliki oplah terbesar dan menjangkau banyak khalayak pembaca. Realitas peristiwa seputar kampanye pemilu, dikontruksi secara berbeda oleh ketiga media cetak ini melalui proses framing.Tipe penelitian ini adalah kualitatif menggunakan paradigma konstruktivis dengan model analisis framing William A Gamson yang menekankan adanya ide sentral dalam setiap pembingkaian berita oleh media massa. Ide sentral tersebut didukung oleh perangkat framing berupa metafora, catchphrases, exemplar, depiction dan visual images. Selain itu ide sentral juga dikuatkan dengan adanya perangkat penalaran berupa roots, appeals to principle dan consequences. Dengan model ini, kemasan peristiwa yang ditampilkan melalui proses framing oleh media massa dapat dianalisa dalam rentang tertentu. Namun tidak sampai menyimpulkan persetujuan dan tidak setuju ataupun keberpihakan dan tidak berpihaknya media massa tersebut kepada salah satu calon kandidat peserta pemilu.Kesimpulan dari penelitian ini menunjukkan unit berita yang diteliti dari Harian Padang Ekspres sebagai objek penelitian memiliki ide sentral yang beragam.

Kata Kunci: Pembingkaian Berita; Kampanye Pemilu 2019; Media Cetak Sumatra Barat

\section{Pendahuluan}

Pemilihan Umum (Pemilu) yang baru saja digelar secara serentak di Indonesia pada 17 April 2019, merupakan agenda nasional yang berbeda dengan perhelatan Pemilu pada tahun-tahun sebelumnya.Penyelenggaraan Pemilihan Legislatif (Pileg) dijadikan satu paket dengan Pemilihan Presiden dan Wakil Presiden (Pilpres).Dengan segala persoalan dan tantangan, Pemilu 2019 telah berjalan sesuai dengan tahapan-tahapannya. Khusus untuk Sumatera Barat, proses rekapitulasi penghitungan suara tingkat Provinsi telah selesai digelar Komisi Pemilihan Umum (KPU) Sumatera Barat pada Minggu sore, 12 Mei 2019.

Pemilu tahun 2019 kembali mempertemukan dua pasangan calon presiden dan wakil presiden.Tidak ada pilihan ketiga, hanya bersifat head to head.Kandidat Calon Presiden (Capres) Joko Widodo kembali ditantang oleh Prabowo Subianto, namun kali ini dengan pasangan Calon Wakil Presiden (Cawapres) yang berbeda.Joko Widodo berpasangan dengan KH Maruf Amin, sedangkan Prabowo Subianto berpasangan dengan Sandiaga Uno. Kedua Capres, Joko Widodo dan Prabowo Subianto sebelumnya telah bertarung juga pada Pilpres tahun 2014 silam. Joko Widodo dinyatakan sebagai pemenang dan dilantik sebagai Presiden.Sementara Prabowo Subianto bersama partai koalisinya dinyatakan sebagai pihak oposisi. 
Berkaca dari potret pemberitaan lima tahun silam, sebagaimana dilaporkan oleh Aliansi Jurnalis Independen (AJI) empat belas hari sebelum pencoblosan Pemilu Legislatif, April 2014, Dewan Pers memaparkan hasil penelitian tiga lembaga independen terkait pemberitaan media. Ketiga lembaga itu adalah Pemantau Regulasi dan Regulator Media (PR2Media), Remotivi, dan Masyarakat Peduli Media (MPM). Menurut AJI, "Hasil penelitian ketiga lembaga tersebut menyimpulkan terjadi banyak pelanggaran kode etik yang paling fundamental dalam praktik jurnalisme, khususnya media penyiaran yakni pemberitaan yang tidak berimbang". ${ }^{1}$

Saat itu, Ketua Dewan Pers, Bagir Manan sebagaimana dikutip dari website resmi Dewanpers.or.id, menyampaikan peringatan etik kepada pemilik perusahaan pers terkait dengan liputan tentang Pemilu 2014.2 Bagir Manan meminta pemilik perusahaan pers untuk tetap menjunjung tinggi kaedah pers, antara lain menghormati pekerja persnya sendiri, termasuk menghormati sikap profesional mereka sebagai jurnalis. Hal itu tertuang dalam pernyataan Bagir Manan “Ada 'pagar api' antara pemilik dan pengelola redaksi. Kita meminta 'pagar api' itu tidak dipadamkan". 3

Dalam penelitian lainnya, Intan Permata Sari menuliskan keterlibatan media yang begitu besar terjadi ketika Pemilihan Presiden tahun 2014.Menurutnya, media pendukung berusaha untuk memenangkan capres pilihannya. Pada saat yang sama ada media lain yang memberikan dukungan yang berbeda kepada calon presiden. Media-media ini bersaing, berusaha semaksimal mungkin memberitakan jagoannya untuk meraih simpati dari masyarakat.Pada saat itu, kepentingan rakyat serasa diabaikan.Rakyat tidak diberi kesempatan untuk berpikir agar bisa memilih dengan benar.Media sibuk menampilkan pencitraan-pencitraan politik.Mereka melakukan pemberitaan-pemberitaan positif dan menyangkal berita-berita negatif yang dapat merugikan calon pilihannya.Pada saat itu pula, pemberitaan yang diberikan oleh media terasa tidak mencerdaskan, dan bersifat subjektif."4

Maka dengan fenomena tersebut, sangat tidak tertutup kemungkinan persoalan serupa akan kembali terulang. Namun untuk membuktikan itu, diperlukan penelitian lebih lanjut tentang pembingkaian berita yang dilakukan media massa pada Pemilu tahun 2019. Salah satu pendekatan yang dapat ditempuh dalam meneliti pembingkaian berita adalah analisis framing.

\footnotetext{
${ }^{1}$ https:/ /aji.or.id/read/press-release/284/Siaran-Pers-Hentikan-Praktik-JurnalismePartisan.html diakses 19 Mei 2019 pukul 16.00 WIB 2https://dewanpers.or.id/publikasi/siaranpers_detail/117/Siaran_Pers:_Dewan_Pers_S ampaikan_Peringatan_Etik diakses 19 Mei 2019 pukul 17.00 WIB

3https://dewanpers.or.id/publikasi/siaranpers_detail/117/Siaran_Pers:_Dewan_Pers_S ampaikan_Peringatan_Etik diakses 19 Mei 2019 pukul 17.00 WIB

${ }^{4}$ Sari, "Keberpihakan Media dalam Pemilihan Presiden 2014," Jurnal Penelitian Komunikasi, Vol 21, No 1 Juli 2018, (Fakultas Tarbiyah dan Tadris IAIN Bengkulu), h.78
} 
Menurut Hafied Cangara, media massa memiliki hubungan yang begitu erat dengan politik. Media massa memainkan peranan yang sangat penting dalam proses politik, bahkan dapat menjadi aktor utama dalam kontestasi politik suatu negara. ${ }^{5}$ Oleh karena itu, sangat tidak tertutup kemungkinan, dengan peranan yang besar itu adakalanya muncul keberpihakan kepada salah satu aktor politik. Di samping itu, A.M Rosenthal sebagai dikutip dari Sobur mengatakan, media massa khususnya surat kabar tidak dapat dipisahkan dari objektivitas sebagai karakter yang membedakan dengan surat kabar lainnya. Karakter objektivitas tersebut membuat pembaca percaya dengan berita yang disampaikan. Karkater itu pula yang membuat surat kabar menjadi memiliki arti dan dihargai publik. Kendati begitu, objektivitas total juga dianggap bersifat mustahil karena setiap berita dibuat oleh wartawan dengan berbagai kondisi emosional. Maka dari itu objektivitas yang paling diharapkan dari wartawan dan redkatur hanyalah mengupayakan objektivitas berita semausiawi mungkin. ${ }^{6}$

Oleh karena itu, penelitian mengenai keberpihakan media masih perlu dikaji kembali pasca Pemilu 2019.Kecenderungan pemimpin redaksi memilih suatu isu dan menonjolkan sisi tertentu dapat ditelaah dalam bentuk analisis framing. Menurut Eriyanto, media bukanlah saluran yang bebas. Media bukanlah seperti yang digambarkan, memberitakan apa adanya, cermin dari realitas. Media justru mengkontruksi sedemikian rupa realitas. Peristiwa yang sama bisa diperlakukan secara berbeda oleh media. Ada peristiwa yang diberitakan ada yang tidak diberitakan.Bahkan, ada media yang menganggap penting, ada pula media yang tidak menganggap isu itu sebagai berita.Intinya, berita yang sampai ke tangan pembaca merupakan hasil konstruksi realitas. ${ }^{7}$

Salah satu pendekatan penelitian yang paling sering digunakan dalam mengkaji media massa adalah analisis framing. Analisis ini dipakai untuk melihat bagaimana media mengkonstruksi realitas.Dengan melakukan analisis framing terhadap berita media, dapat menentukan framing media dalam mengkonstruksi realitas politik.Eriyanto menguraikan bahwa terdapat dua esensi utama dari sebuah framing.Pertama, dipakai untuk melihat bagaimana peristiwa dimaknai, hal ini berhubungan dengan bagian mana yang diliput dan bagian mana yang tidak diliput.Kedua, tentang bagaimana fakta ditulis, dimana aspeknya berhubungan dengan pemakaian kata, kalimat dan gambar untuk mendukung gagasan. ${ }^{8}$

Surat kabar sebagai salah satu media massa tertua yang masih bertahan sampai hari ini, tetap menjadi sumber informasi yang cukup dipercaya oleh khalayak pembacanya. Meskipun dihadapkan dengan tantangan digitalisasi, surat kabar dianggap belum akan mati dalam waktu dekat. Hal ini sebagaimana diungkapkan peneliti senior di Lembaga Studi Pers dan Pembangunan,

5Cangara, Pengantar Imu komunikasi, (Jakarta: Rajawali Press, 2008), 117.

'Sobur, Analisis Teks Media: Suatu Pengantar Analisis Wacana, Analisis Semiotika dan Analisis Framing, (Bandung: Remaja Rosdakarya, 2012), 170.

${ }^{7}$ Eriyanto, Analisis Framing, Konstruksi, Ideologi dan Politik Media, (Yogyakarta: LKIS, 2001), h. 2.

${ }^{8}$ Eriyanto, Analisis Framing......, 11. 
IgnatiusHaryanto kepada Tirto.id. Dia masih optimistis bahwa media cetak seperti koran harian, tidak bakalan mati, meskipun mengalami pelambatan dalam segi pertumbuhan bisnis. ${ }^{?}$

Menurut Haryanto, surat kabar sampai hari ini masih memiliki kelebihan yang belum dikuasai oleh media daring. Pada 2015, Haryanto mengunjungi dua kota di Kalimantan untuk bertemu dengan pengelola media lokal di sana yang sama-sama menegaskan bahwa pengaruh media daring (online) terhadap bisnis dan eksistensi koran belum signifikan. Bisnis media cetak masih berjalan baik, koran masih dibeli masyarakat. Kesimpulannya, selama kualitas jurnalisme masih baik dan teruji alias bukan berita bohong (hoaks) maka produk jurnalistik akan tetap dibaca, apapun mediumnya.

Di Sumatra Barat, sedikitnya terdapat tujuh media cetak yang terbit setiap hari. Media cetak ini jika dikategorisasikan menurut periode terbitnya, biasa dikenal dengan koran harian. Yaitu Harian Umum Singgalang, Harian Haluan, Harian Padang Ekspres, Posmetro Padang, Koran Padang, Harian Rakyat Sumbar dan Metro Andalas.

Dari tujuh koran harian tersebut, Harian Padang Ekspres menjadi satusatunya koran berjaringan nasional di bawah naungan perusahaan Jawa Pos Group. Harian Padang Ekspres juga menjadi induk yang melatarbelakangi sekaligus menaungi lahirnya Posmetro Padang dan Harian Rakyat Sumbar dengan bendera Padek Group.Sisanya, merupakan media cetak yang terbit atas perusahaan lokal yang sahamnya dimiliki oleh pengusaha Sumatra Barat dan mengedepankan pemberitaan lokal sebagai sajian utama kepada khalayak pembacanya.

Berdasarkan arsip perusahaan, Harian Padang Ekspres dalam rentang waktu kampanye Pemilu yang dimulai 23 September 2018 sampai 13 April 2019, pemilihan isu politik seputar pemilu yang berkaitan langsung dengan kandidat Capres dan Cawapres hanya terdapat 11 kali yang ditampilkan sebagai headline di halaman utama. Yaitu sebanyak 4 kali di tahun 2018 dan ketika memasuki tahun 2019, jumlah headline tersebut disajikan sebanyak 8 kali edisi.

Salah satunya seperti berita yang dimuat Harian Padang Ekspres pada edisi Minggu, 17 Februari 2019 dengan judul Headline: Jokowi Fokus Substansi, Prabowo Tampil Orisinil. Harian Padang Ekspres menggambarkan sosok Jokowi sebagai calon yang sangat siap dengan materi debat dan akan fokus pada materi. Sementara itu sosok Prabowo dikontruksikan sebagai calon yang sudah memiliki gaya dan identitas selayaknya sudah melekat di pikiran pembaca.

Dengan adanya penggambaran karakteristik calon presiden dan wakil presiden dalam pemberitaan Harian Padang Ekspres seperti dijelaskan di atas, maka dapat diprediksi tiap pemberitaan yang mengangkat isu kedua calon, akan ditampilkan dalam kontruksi framing yang berbeda. Hal ini dikuatkan oleh pengakuan Pemimpin Redaksi Harian Padang Ekspres, Heri Sugiarto berikut ini:

\footnotetext{
${ }^{9}$ https:// tirto.id/media-cetak-bisa-mati-jurnalisme-seharusnya-tidak-ciy6 diakses September 2019 pukul 22.45 WIB
} 
"Kami netral saja. Jika Prabowo berkampanye di Padang, maka tentu akan menjadi isu utama untuk dijadikan Headline di halaman depan. Jika nanti ada kampanye Jokowi di Sumbar, kami akan muat juga di halaman depan. Sejaub ini kami alhamdulillah tetap berusaha independen tidak terbawa arus. Namun kami juga tidak akan berani melawan arus pembaca di Sumbar yang katanya basis fanatik. kubu Prabowo" (wawancara dengan Heri Sugiarto 13 Mei 2019)

Secara tidak langsung Heri Sugiarto menyampaikan bahwa kebijakan redaksi harus sejalan dengan kemauan pembaca. Artinya, apa yang dianggap penting oleh publik, menjadi penting pula oleh media.

Oleh sebab itu, penulis ingin melakukan penelitian seputar pembingkaian berita calon presiden dan wakil presiden selama kampanye pemilu tahun 2019 yang difokuskan pada analisis framing berita di halaman utama Harian Padang Ekspres.

Penelitian ini ditujukan untuk mengetahui bagaimana sebuah media mengkontruksi realitas atas suatu peristiwa. Oleh karena itu, demi menjawab rumusan masalah yang telah disebutkan di atas, maka penulis menetapkan tujuan penelitian yang ingin dicapai yaitu untuk mendeskripsikan pembingkaian berita calon presiden dan wakil presiden selama kampanye pemilu di tahun 2019 pada berita di halaman utama Harian Padang Ekspres menurut analisis framing model William A Gamson.

\section{Hasil dan Pembahasan}

Menurut Alex Sobur, gagasan mengenai framing, pertama kali dilontarkan oleh Beterson tahun 1955. Mulanya, frame dimaknai sebagai struktur konseptual atau perangkat kepercayaan yang mengorganisir pandangan politik, kebijakan, dan wacana, serta yang menyediakan kategori-kategori standar untuk mengapresiasi realitas.Konsep ini kemudian dikembangkan lebih jauh oleh Goffman pada 1974, yang mengandaikan frame sebagai kepingan-kepingan perilaku (strips of behavior) yang membimbing individu dalam membaca realitas. ${ }^{10}$

Namun, kemudian pengertian framing berkembang yaitu ditafsirkan untuk menggambarkan proses penseleksian dan penyorotan aspek-aspek khusus sebuah realita oleh media. Menurut Eriyanto, dalam sebuah berita tersirat pesan yang ingin disampaikan oleh jurnalis terhadap masyarakat pembaca. Seorang jurnalis memasukkan ide-ide mereka dalam melakukan analisis dan menulis berta dari data-data yang diperoleh dilapangan. Hal lain yang tak kalah berpengaruh tentunya visi, misi dan ideologi yang dimiliki oleh media itu dan tentunya juga akan diikuti oleh pekerja media tersebut. Visi, misi dan ideologi ini tentunya juga akan tercermin dalam konstruksi realitas yang dilakukan oleh media yang bersangkutan. Hal ini tentunya juga mempengaruhi framing yang dilakukan pada sebuah wacana. ${ }^{11}$

\footnotetext{
10Sobur, Analisis Teks Media....., 161-162.

${ }^{11}$ Eriyanto, Analisis Framing......, 145.
} 
Jika dikaitkan dengan realitas peristiwa, framing menentukan bagaimana realitas hadir di hadapan pembaca. Jika seorang wartawan mempunyai bingkai yang berbeda melihat suatu peristiwa, lalu kemudian menuliskan berita sesuai pandangannya itu maka framing dapat mengakibatkan suatu peristiwa yang sama namun beritanya berbeda. Menurut Eriyanto, analisis framing akan membantu mengungkap bagaimana realitas peristiwa itu dikemas. ${ }^{12}$

Di lain pihak, Dietram A Scheufele menyebut, framing pemberitaan merupakan perpanjangan dari teori agenda setting, yaitu semacam teknik yang dipakai wartawan untuk melahirkan wacana yang akan ditangkap oleh khalayak. Secara praktis, framing bisa dilihat dari cara media massa memilih dan memilah bagian dari realitas dan menjadikannya bagian yang penting dari sebuah teks berita Secara praktis, framing bisa dilihat dari cara media massa memilih dan memilah bagian dari realitas dan menjadikannya bagian yang penting dari sebuah teks berita. ${ }^{13}$

Penelitian ini menggunakan pendekatan analisis framing dengan model William A Gamson. Konsep ini ditulis Gamson bersama Andre Modigliani serta cukup banyak dipakai dalam berbagai penelitian teks media. Konsep dasar model ini berpandangan bahwa struktur internal berita akan selalu ada dalam sebuah frame sebagai pusat organisasi ide pemberitaan tersebut. Hal inilah yang membuat peristiwa menjadi relevan hingga menekankan suatu isu. Bagi Gamson, frame tidaklah sama dengan sikap setuju atau tidak setuju akan suatu hal, melainkan memiliki rentang posisi tertentu. Framing, katanya, tidak berhubungan dengan orientasi pemberitaan, akan tetapi bagaimana suatu peristiwa dibingkai dan disajikan kepada khalayak.

Menurut Eriyanto, dalam formulasi yang dibuat oleh Gamson dan Modigliani frame digambarkan sebagai cara bercerita atas gugusan ide yang disusun sedemikian rupa dan menghadirkan konstruksi makna dari sebuah peristiwa. Menurutnya, berita media terdiri dari sejumlah kemasan (package).Kemasan itu merupakan skema atau struktur pemahaman yang dipakai oleh seseorang ketika mengkonstruksi pesan yang dia sampaikan dan menafsirkan pesan yang diterimanya. Artinya, framing adalah pendekatan untuk mengetahui bagaimana perspektif atau cara pandang wartawan ketika menyeleksi isu dan menulis berita. ${ }^{14}$

Kemasan atau yang disebut package oleh Gamson tadi, adalah wadah untuk mengorganisir sejumlah informasi yang menunjukkan posisi atau kecenderungan politik dan yang membantu komunikator menjelaskan muatan-muatan di balik isu atau peristiwa. Package akan terlihat dari gagasan sentral yang didukung oleh perangkat-perangkat. Untuk lebih jelasnya, perangkat framing yang dikemukakan Gamson dan Modigliani dapat digambarkan sebagai berikut:

\footnotetext{
12Ibid., 97.

${ }^{13}$ Scheufele, "Framing As a Theory of Media Effects," The Journal of Communication, 49, 1999, 103.

${ }^{14}$ Eriyanto, Analisis Framing......, 261.
} 
Tabel. 1. Perangkat Framing Model William A Gamson

\begin{tabular}{|l|l|}
\hline \multicolumn{2}{|c|}{ Frame Central : ...................... } \\
\hline $\begin{array}{l}\text { Framing Devices } \\
\text { (Perangkat Framing) }\end{array}$ & $\begin{array}{l}\text { Reasoning Devices } \\
\text { (Perangkat Penalaran) }\end{array}$ \\
\hline $\begin{array}{l}\text { Methapors } \\
\text { Perumpamaan atau pengandaian }\end{array}$ & $\begin{array}{l}\text { Roots } \\
\text { Analisis kausal atau sebab akibat }\end{array}$ \\
\hline $\begin{array}{l}\text { Catchphrases } \\
\text { Frase yang menarik, kontras, menonjol } \\
\text { dalam suatu wacana, umumnya berupa } \\
\text { jargon atau slogan. }\end{array}$ & $\begin{array}{l}\text { Appeals to principle } \\
\text { Premis dasar atau klaim-klaim moral }\end{array}$ \\
\hline $\begin{array}{l}\text { Exemplaar } \\
\text { Mengaitkan bingkai dengan contoh } \\
\text { atau uraian yang memperjelas bingkai }\end{array}$ & Eonsequences \\
\hline $\begin{array}{l}\text { Depiction } \\
\text { Penggambaran suatu isu yang bersifat didari bingkai } \\
\text { kiasan, biasanya berupa kosakata untuk } \\
\text { melabeli sesuatu }\end{array}$ & \\
\hline $\begin{array}{l}\text { Visual Images } \\
\text { Dapat berupa gambar, grafik, karikatur } \\
\text { atau foto untuk mendukung pesan } \\
\text { yang disampaikan }\end{array}$ & \\
\hline
\end{tabular}

Berdasarkan tabel model framing yang dikemukakan oleh Gamson tersebut, setiap berita memiliki ide sentral atau frame utama yang didukung oleh dua perangkat dengan beberapa elemen pendukung.Perangkat framing bisa didukung oleh elemen-elemen seperti kata-kata atau kalimat tertentu ditambah dengan penampilan gambar dan foto untuk mendukung gagasan tertentu.Sedangkan perangkat penalaran lebih kepada kohesi dan koherensi dari teks tersebut.Eriyanto mengilustrasikan dengan seorang penceramah yang menyampaikan gagasan tertentu.Agar gagasan diterima khalayak, penceramah itu harus membuat pesan yang disampaikannya tampak wajar dan beralasan.Satu bagian tampak mendukung bagian lainnya, antar kalimat saling mendukung atau satu bagian menjadi sebab dan akibat atas bagian lainnya.Sehingga gagasannya terlihat beralasan sesuai fakta, ilmiah, benar dan tidak mengada-ada.Penceramah 
juga perlu menekankan gagasannya dengan perangkat framing tertentu agar tidak hanya terlihat wajar tapi juga meyakinkan. ${ }^{15}$

Dalam komunikasi massa, media adalah alat yang menghubungkan sumber dan penerima yang sifatnya terbuka di mana setiap orang bisa melihat, membaca, dan mendengar-nya. Dalam media, berita merupakan salah satu elemen dasar proses komunikasi.Pengertian berita yang bersifat akademik dikemukakan oleh Dean M Lyle Spencer dari Universitas Washington.Spencer mengatakan berita adalah suatu peristiwa, gagasan, ataupun opini yang pada saatnya bersifat penting atau berpengaruh terhadap banyak orang dalam masyarakat. ${ }^{16}$

Sementara itu, menurut Rolnicki, berita headline merupakan berita utama yang ditampilkan oleh sutau media yang biasanya ditempatkan dihalaman utama (depan) dengan judul yang dicetak lebih besar dibanding judul berita yang lain. Posisinya biasanya diletakkan di bagian atas tengah, kiri, atau kanan.Biasa pula ditempatkan di bagian tengah. Editor membedakan dua jenis headline yakni headline teaser (penggoda) atau teller (pemberitahu). Headline teaser berusaha menarik perhatian dengan meringkaskan berita penting secara jelas dan tepat. Sedangkan beadline teller biasanya langsung kesasaran yang didesain dengan menggunakan satu atau dua jenis huruf standar. ${ }^{17}$

Headline merupakan intisari dari berita. Dibuat dalam satu atau dua kalimat pendek, tetapi cukup memberitahukan persoalan pokok peristiwa yang diberitakannya. Menurut Suhandang dikutip Rolnicki, variasi penyajian headline diusahakan agar khalayak tertarik untuk menikmati pemberitaanya. Headline berfungsi untuk memanggil khalayak agar mau membaca, mendengar, atau menontonnya. Surat kabar tidak menurunkan headline secara asal-asalan melainkan mengikuti beberapa pedoman seperti harus akurat, informatif, fair, dan tidak meletakkan sesuatu yang tidak ada dalam berita.

Sejumlah penelitian tentang headline surat kabar berkaitan dengan pemilu telah banyak dilakukan. Di antaranya Hariyadi, yang menggunakan model analisis framing Robert N. Entman untuk menganalisis pembingkaian berita sebagai upaya menjaga citra positif DPRD Sumatera Barat. ${ }^{18}$ Selanjutnya, Rully Febriansyah juga menggunakan model yang sama untuk menganalisis bingkai berita kebijakan publik pemerintah Kabupaten Tagalong. ${ }^{19}$ Sementara itu, Ricky Alkat Seftiano menggunakan teori agenda setting untuk menganalisis pemberitaan pemilihan Gubernur Kalimantan Timur tahun 2013.20Adapun

15Ibid.,h. 265-266.

${ }^{16}$ Cangara, Pengantar Ilmu Komunikasi......, 25

${ }^{17}$ Rolnicki, Pengantar Dasar Jurnalisme (Scholastic Journalism), (Jakarta: Kencana, 2008), 224.

${ }^{18}$ Hariyadi, "Pembingkaian Berita dalam Upaya Menjaga Citra Positif DPRD Provinsi Sumatera Barat: Analisis Framing Rubrik Majalah Mimbar Tahun 2014-2015,” (Master Tesis, UPT, Perpustakaan Universitas Andalas, 2015).

${ }^{19}$ Febriansyah, "Bingkai Berita Kebijakan Publik Pemerintah Kabupaten Tabalong: Analisis Framing Kolom Kontrak Pemberitaan Surat Kabar Regional Kalimantan Selatan Tahun 2013,’(Master Tesis, UPT, Perpustakaan Universitas Andalas, 2016).

20Seftiano, “Analisis Framing Pemberitaan Pemilihan Gubernur Kalimantan Timur 2013 Surat Kabar Kaltim Post dan Tribun Kaltim pada Masa Kampanye," (Universitas Mulawarman: Jurnal Ilmu Komunikasi, 2014). 
penelitian ini fokus pada pembingkaian berita pada halaman utama Harian Padang Ekspres yang menampilkan pemberitaan seputar kandidat calon presiden dan wakil presiden dalam masa kampanye pemilu tahun 2019 yang kemudian ditelaah menggunakan analisis framing model William A Gamson.

\section{Metode Penelitian}

Penelitian ini menggunakan metode kualitatif dengan paradigma konstruktivis, dimana paradigma ini mempunyai posisi dan pandangan tersendiri terhadap media dan teks berita yang dihasilkannya.Paradigma ini memandang realitas kehidupan sosial bukanlah realitas yang natural, melainkan hasil dari konstruksi. Konsentrasi analisis pada paradigma konstruksionis adalah menemukan bagaimana peristiwa atau realitas tersebut dikonstruksi, dengan cara apa konstruksi itu dibentuk.

Data Primer atau data utama dalam penelitian ini berupa teks berita yang dikumpulkan sesuai batasan masa kampanye pemilu di tahun 2019, yaitu setiap berita Harian Padang Ekspres yang berada pada halaman utama, serta berisikan topik seputar kandidat calon presiden dan calon wakil presiden. Data pendukung atau data sekunder dalam penelitian ini berasal dari hasil wawancara peneliti dengan Pemimpin Redaksi Harian Padang Ekspres yaitu Bapak Heri Sugiarto.Penelitian ini didukung juga dengan data-data yang bersumber dari buku-buku, naskah berita di portal online, jurnal penelitian yang relevan, dan arsip-arsip lain yang berkaitan.

Dalam pengumpulan data yang diperlukan dalam penelitian ini, peneliti menggunakan teknik pengumpulan data dengan cara melakukan kliping berita dari ketiga media cetak yang menjadi objek penelitian yaitu Harian Padang Ekspres yang memuat isu seputar pemilu presiden dan wakil presiden selama masa kampanye di tahun 2019. Namun untuk menjadikan penelitian ini lebih aktual, dimana masa kampanye secara resmi yang terhitung sejak tanggal 23 September 2018 sampai - 13 April 2019, maka penelitian ini hanya mengambil sampel pemberitaan yang terbit menjelang pemilihan umum khusus di tahun 2019 saja. Total berita yang dapat dikategorikan dengan kriteria tersebut di Harian Padang Ekspres berjumlah 8 berita.

Kliping berita yang telah dipilih tersebut sebagaimana dijelaskan dalam tabel 3.4 di atas akan dianalisis menggunakan perangkat framing model William A Gamson sebagaimana yang terangkum dalam tabel di bawah ini :

Tabel 3.5 Konsep Analisis Framing Model William A Gamson

\begin{tabular}{|l|l|}
\hline \multicolumn{2}{|c|}{ Frame Central : $\ldots \ldots \ldots \ldots \ldots \ldots \ldots \ldots \ldots \ldots$} \\
\hline $\begin{array}{l}\text { Framing Devices } \\
\text { (Perangkat Framing) }\end{array}$ & $\begin{array}{l}\text { Reasoning Devices } \\
\text { (Perangkat Penalaran) }\end{array}$ \\
\hline $\begin{array}{l}\text { Methapors } \\
\text { Perumpamaan atau pengandaian }\end{array}$ & $\begin{array}{l}\text { Roots } \\
\text { Analisis kausal atau sebab akibat }\end{array}$ \\
\hline Catchphrases & Appeals to principle \\
\hline
\end{tabular}




\begin{tabular}{|l|l|}
\hline $\begin{array}{l}\text { Frase yang menarik, kontras, menonjol } \\
\text { dalam suatu wacana, umumnya berupa } \\
\text { jargon atau slogan. }\end{array}$ & Premis dasar atau klaim-klaim moral \\
\hline $\begin{array}{l}\text { Exemplaar } \\
\text { Mengaitkan bingkai dengan contoh } \\
\text { atau uraian yang memperjelas bingkai }\end{array}$ & $\begin{array}{l}\text { Consequences } \\
\text { Efek yang didapat dari bingkai }\end{array}$ \\
\hline $\begin{array}{l}\text { Depiction } \\
\text { Penggambaran suatu isu yang bersifat } \\
\text { kiasan, biasanya berupa kosakata untuk } \\
\text { melabeli sesuatu }\end{array}$ & \\
\hline $\begin{array}{l}\text { Visual Images } \\
\text { Dapat berupa gambar, grafik, karikatur } \\
\text { atau foto untuk mendukung pesan } \\
\text { yang disampaikan }\end{array}$ & \\
Sumber: Eriyanto
\end{tabular}

Berdasarkan model framing tersebut, peneliti akan memaparkan hasil penelitian dengan tiga kelompok pembahasan yang terdiri dari:

1. Frame Central yaitu seperangkat gagasan atau ide sentral yang dipakai media untuk memahami dan memaknai suatu isu.

2. Perangkat Framing yaitu bagian-bagian yang berhubungan langsung dengan ide sentral dan ditekankan dalam teks berita.

3. Perangkat Penalaran yaitu berhubungan dengan kohesi dan koherensi dari teks yang merujuk pada gagasan, alasan dan penalaran tertentu.

\section{Pembingkaian Berita Harian Padang Ekspres Edisi Jumat, 18 Januari 2019}

Pada edisi Jumat, 18 Januari 2019, Harian Padang Ekspres menampilkan berita di halaman utama dengan judul "Debat Panas Lalu Berpelukan, CapresCawapres Tak Singgung Kasus Novel”.Berita ini memiliki ide sentral yaitu kedua pasangan kandidat capres-cawapres ahli dalam berdebat.

Dalam pandangan Harian Padang Ekspres kedua kandidat sama-sama memiliki kemampuan untuk menyuguhkan debat yang menarik. Bahkan, pada lead pembuka berita, Harian Padang Ekspres menyebutkan adanya aksi saling sindir yang membuat perdebatan kedua kandidat berlangsung panas. Aksi saling sindir ini bahkan dijelaskan dalam beberapa contoh kalimat yang terlontar dari para kandidat beserta jawaban langsung kandidat lainnya. Misalnya pada kutipan berikut:

"Yang tampak dalam debat adalah aksi saling sindir. Misalnya, saat Prabowo mempersoalkan seorang lurah di Mojokerto yang diproses hukum gara-gara mendukung dirinya dan Sandi.Sebaliknya, Jokowi balas menyentil mantan pendukung Prabowo-Sandi yang menebar hoaks." 
Selain menunjukkan debat yang berlangsung seru, Harian Padang Ekspres juga menyoroti adanya sejumlah isu yang diharapkan menjadi topik menarik, namun justru tidak dibahas oleh kedua kandidat. Seperti dalam kutipan paragraf kedua berikut:

"Ada empat tema besar yang menjadi materi debat. Yakni, hukum, korupsi, hak asasi manusia (HAM), dan terorisme.Kedua paslon memaparkan program unggulan masingmasing di empat bidang tersebut.Namun, beberapa isu besar aktual malah tidak disebut.Misalnya, kasus penyiraman air keras dengan korban penyidik Komisi Pemberantasan Korupsi (KPK) Novel Baswedan.Sudah lebih dari 600 hari kasus tersebut tidak terungkap. Kasus besar lain yang tak disinggung, antara lain, korupsi Bank Century hingga penculikan aktivis."

Pemikiran yang dikembangkan oleh Harian Padang Ekspres dalam berita tersebut didukung dengan pemakaian simbol tertentu untuk menekankan arti yang ingin dikembangkan dalam teks berita.Tujuannya untuk memberi kesan efek penonjolan makna yang disajikan.Simbol-simbol tersebut dapat diamati dari pemakaian kata, kalimat, grafis dan foto utama.

Perangkat pembingkai berita dipakai untuk memberi citra bahwasanya suasana debat memang berlangsung panas namun diakhiri dengan keakraban. Harian Padang Ekspres bahkan memberikan metafora dengan kalimat seperti berikut:

"Ada momen-momen unik yang tak tampak di layar televisi tadi malam.Misalnya, keakraban kedua paslon hingga para pendukung di dalam maupun luar gedung yang menyemangati jagoan masing-masing."

Metafora itu dijadikan kalimat yang mengakhiri pembahasan seputar isi debat. Untuk menekankan bahwa sekalipun debat telah usai di layar televisi, suasana di luar gedung tempat berlangsungnya acara debat juga diramaikan oleh para pendukung. Harian Padang Ekspres menggunakan kata "jagoan” bagi kedua kandidat yang penampilannya begitu memukau dan dipuja oleh para pendukungnya.

Penonjolan kata yang ditampilkan dalam teks berita antara lain adalah aksi sindir dan pemaparan fokus visi-misi. Harian Padang Ekspres menekankan selain aksi saling sindir, kedua paslon memaparkan program unggulan masingmasing.Bedanya, Jokowi lebih berfokus membenahi sistem.Sementara itu, Prabowo memilih berfokus pada peningkatan kesejahteraan para penegak hukum.

Pemberian label (depiction) dengan menggunakan kalimat tertentu juga dilakukan dalam pembingkaian berita tersebut, diantaranya label ini 
dipertentangkan dengan penilaian lain bahwasanya keduanya tidak mampu menguasai debat. Secara eksplisit, Harian Padang Ekspres menyayangkan kedua kandidat tidak membahas isu besar yang aktual. Untuk melabeli kenyataan tersebut, Harian Padang Ekspres menekankan bahwa kedua kandidat sangat akrab dan saling menghormati satu sama lain. Hal itu dapat dilihat dalam kalimat:

"Jokowi dan Ma'ruf mendatangi Prabowo dan Sandiaga.Jokowi dan Prabowo berpelukan hangat.Keduanya menyunggingkan senyum yang lebar, bahkan tertawa.Prabowo terlihat mengguncang-guncang pundak Jokowi sambil tertawa.Sementara itu, Sandiaga berkali-kali mencium tangan Ma'ruf."

Harian Padang Ekspres juga memberikan ilustrasi (exemplaar) dengan menampilkan kejadian di luar panggung debat antara tokoh partai politik yang berlawanan. Hal itu untuk mengarahkan pembingkaian aksi saling sindir dalam debat nyatanya tidak berujung pada permusuhan, melainkan sebaliknya. Ilustrasi tersebut dapat dilihat pada kutipan item paragraf berikut:

"Tadi malam beredar foto selfie sejumlah tokoh.Ketua Umum PDIP Megawati Soekarnoputri tampak ber-wefie dengan Prabowo dan Sandiaga, serta Nur Asia Uno.Yang mengambil gambar adalah Puan Maharani.Keduanya terlihat tersenyum semringah.Sama sekali tidak ada kesan persaingan.Megawati dan Prabowo memang punya kedekatan.Sebab, keduanya pernah maju bersama pada Pilpres 2009.”

Berita ini juga menampilkan visual images keterangan foto ini merupakan penguatan simbolis atas keakraban kedua kandidat dimana memperlihatkan foto kedua kandidat mencairkan suasana usai debat dengan berjabat tangan. Menunjukkan suasana panas saat debat ditutup dengan kekeluargaan.

Pemikiran yang dikembangkan dalam berita ini yaitu kedua kandidat ahli dalam berdebat dikuatkan dengan perangkat penalaran yang menunjukkan kebenaran atas fakta-fakta tersebut.Harian Padang Ekspres menekankan bahwa penyampaian informasi dengan gaya bercerita bagaimana jalannya sebuah acara debat telah disesuaikan dengan perspektif penulis berita. Perangkat penalaran itu disampaikan dengan roots yaitu debat kandidat menggambarkan skill calon presiden dan wakil presiden dalam memaparkan visi dan misi. Kedua kandidat juga menjunjung tinggi sportivitas dan persahabatan ketika perdebatan telah usai.

Perangkat penalaran juga dipakai untuk membantah anggapan bahwa kedua kandidat hanya menghapal teks dan tidak tampil apa adanya. Harian Padang Ekspres bahkan memberi klaim-klaim moral tertentu (appeals to principle). Salah satu yang disorot adalah keduanya sering ditegur oleh moderator debat karena tidak menghentikan pembicaraan saat waktu telah habis. Di sisi lain, tingginya antusiasme para pendukung saat kandidat tampil juga memberi bukti bahwa perdebatan benar-benar menghibur, sebagaimana dinukilkan dalam kutipan: 
"Saat paparan visi-misi, kedua paslon sama-sama menyampaikan program melebihi waktu yang ada.Alhasil, para moderator terus-menerus mengingatkan mereka."

Konsekuensi yang ditampilkan dengan ide framing kedua kandidat sangat ahli dalam berdebat yaitu sulitnya mengontrol audiens. Penonton disebut tidak menghormati aturaan-aturan yang sudah dibacakan oleh panitia debat sebelum acara dimulai. Hal itu dapat dilihat dalam kutipan berikut:

"Sebagaimana sudah diduga, tepuk tangan di tengah paparan maupun sesi jawaban tetap terdengar.Padahal, KPU sudah melarang.Moderator pun berkali-kali menegur para pendukung paslon agar tenang."

Untuk lebih jelas mengenai pembingkaian berita Harian Padang Ekspres edisi Jumat, 18 Januari 2019 dapat dilihat dari tabel berikut ini:

Tabel 5.1 Pembingkaian Berita Harian Padang Ekspres Edisi Jumat, 18 Januari 2019

\begin{tabular}{|c|c|}
\hline \multicolumn{2}{|c|}{ Frame Central : Kedua Kandidat Capres-Cawapres Ahli Berdebat } \\
\hline $\begin{array}{l}\text { Framing Devices } \\
\text { (Perangkat Framing) }\end{array}$ & $\begin{array}{l}\text { Reasoning Devices } \\
\text { (Perangkat Penalaran) }\end{array}$ \\
\hline $\begin{array}{l}\text { Methapors } \\
\text { Menggunakan kata "jagoan" bagi } \\
\text { kedua kandidat yang penampilannya } \\
\text { begitu memukau dan dipuja oleh para } \\
\text { pendukungnya. }\end{array}$ & $\begin{array}{l}\text { Roots } \\
\text { Debat kandidat menggambarkan skill } \\
\text { calon presiden dan wakil presiden } \\
\text { dalam memaparkan visi dan misi. } \\
\text { Kedua kandidat juga menjunjung tinggi } \\
\text { sportivitas dan persahabatan ketika } \\
\text { perdebatan telah usai }\end{array}$ \\
\hline $\begin{array}{l}\text { Catchphrases } \\
\text { Aksi sindir dan pemaparan fokus visi- } \\
\text { misi }\end{array}$ & $\begin{array}{l}\text { Appeals to principle } \\
\text { Kedua kandidat sering ditegur oleh } \\
\text { moderator, tingginya antusiasme para } \\
\text { pendukung saat kandidat tampil. }\end{array}$ \\
\hline $\begin{array}{l}\text { Exemplaar } \\
\text { menampilkan kejadian di luar } \\
\text { panggung debat antara tokoh partai } \\
\text { politik yang berlawanan. }\end{array}$ & $\begin{array}{l}\text { Consequences } \\
\text { Sulit mengatur audiens. Penonton } \\
\text { disebut tidak menghormati aturan- } \\
\text { aturan yang sudah dibacakan oleh } \\
\text { panitia debat sebelum acara dimulai. }\end{array}$ \\
\hline $\begin{array}{l}\text { Depiction } \\
\text { menekankan kedua kandidat sangat } \\
\text { akrab dan saling menghormati satu } \\
\text { sama lain sebagai kiasan bahwasanya } \\
\text { ada isu aktual tentang penegakan } \\
\text { hukum yang sama-sama dilupakan oleh }\end{array}$ & \\
\hline
\end{tabular}




\begin{tabular}{|l|l|}
\hline mereka. & \\
\hline Visual Images & \\
Untuk mendukung pesan yang & \\
disampaikan ada foto kedua kandidat & \\
saling bersalaman disertai penampilan & \\
grafis fakta dan data materi debat para & \\
kandidat. & \\
\hline
\end{tabular}

\section{Pembingkaian Berita Harian Padang Ekspres Edisi Kamis, 4 April 2019}

Harian Padang Ekspres memberi judul headline pada edisi Kamis, 4 April 2019 dengan "100 Hari Janji Listrik dan Sembako Turun, Terima Sumbangan, Prabowo Teteskan Airmata di Padang. Ide sentral pembingkaian berita ini adalah sosok Prabowo Subianto menjanjikan kesejahteraan masyarakat.

Ide sentral tersebut didukung oleh perangkat pembingkaian yang komplit.Dengan menggunakan pengandaian kondisi kekayaan negara yang hanya dinikmati oleh segelintir orang, Prabowo Subianto digambarkan sebagai penyelamat.

"Menurutnya, sistem ekonomi yang berdasar Pancasila merupakan sistem yang berkeadilan sosial bagi seluruh rakyat, bukan hanya untuk segelintir orang. "Indonesia adalah negara yang amat kaya.Namun kekayaan itu diambil dan dibawa lari ke luar negeri," bebernya."

Metafora yang ditampilkan adalah sistem ekonomi berasaskan pancasila, namun kekayaan hanyalah milik segelintir orang.Penyematan gelar kaya bagi segelintir orang diikuti dengan membawa kekayaan alam Indonesia ke luar negeri. Kalimat-kalimat ini digunakan untuk mendukung pembingkaian bahwasanya sosok Prabowo Subianto akan menjadi pemimpin yang mensejahterakan seluruh rakyat.

Penonjolan yang terjadi dalam berita ini adalah penekanan pada kalimat memberikan jiwa dan raga untuk kemajuan Indonesia.Dengan bingkai menjanjikan kesejahteraan rakyat, Harian Padang Ekspres menekankan kalimat Prabowo Subianto tidak bisa memberikan amplop dan sembako. Namun jauh dari itu, yang akan diberikan adalah jiwa raga. Penonjolan kalimat untuk mendukung gagasan (catchphrases) seperti ini dapat dijumpai pada paragraf berikut:

"Dalam kampanyenya, Prabowo sempat melontarkan permintaan maaf kepada para pendukung.Dia meminta maf lantaran tak bisa memberikan uang dan sembako kepada para pendukungnya. Namun, Prabowo mengaku bakal memberikan dirinya untuk masyarakat dan masa depan generasi muda bangsa."

Bingkai yang sudah dibangun tersebut juga dikaitkan dengan contoh lain pada kalimat berikutnya. Dapat dijumpai uraian yang memperjelas bingkai (exemplaar) yang mempertegas bahwa Prabowo Subianto ingin mensejahterakan masyarakat dengan cara tidak memperkaya diri sendiri. Memberikan penegasan 
bahwa Prabowo Subianto adalah sosok pemimpin yang adil. Sebagimana dijelaskan Ubaedillah (2008:49), seorang pemimpin disyaratkan harus adil, karena pemimpin yang adil tidak akan menggunakan kekuasaan demi ambisinya atau untuk menindas orang-orang yang dipimpinnya, tidak akan menggunakan kekuasaan untuk memperkaya diri sendiri atau orang lain yang ada hubungan dengan dirinya. Serta tidak menggunakan kekuasaan untuk membuat kebijakankebijakan yang menguntungkan diri sendiri, dan menjadikan hukum sebagai tonggak pertama yang harus ditegakkan dalam sebuah negara demokrasi. Penegasan ini dapat dilihat dalam kutipan paragraf berikut ini:

"Menurut Prabowo, niatnya maju di Pilpres 2019 ini murni ingin menyelamatkan kekayaan negara. Oleh sebab itu, jika terpilih, dia bersumpah tidak akan memperkaya diri dan keluarganya."

Kalimat tersebut diperkuat lagi pada bagian kalimat lainnya yang mengulangi pernyataan tersebut. Seperti dijumpai pada kutipan kalimat langsung dari Prabowo Subianto berikut ini:

"Banyak sekali program kita, tapi saya tidak ingin sekadar janji, tapi ingin berjuang untuk Indonesia ini.15 hari lagi saya minta kalian pulang ke kampung, pulang ke rumahnya, pulang ke RT, yakinkan kepada tetanggamu.Kalau saya mendapat mandat, saya tidak akan memperkaya diri dan saudara saya," pungkasnya."

Dari segi perangkat depiction atau penggambaran suatu isu yang bersifat kiasan, juga diselipkan pada pemberitaan ini secara gamblang.Seperti adanya pembahasan khusus bagaimana Prabowo Subianto menitikkan airmata saat mendapatkan sumbangan dari para pendukung. Hal itu dapat ditemui pada pargraf berikut ini:

"Prabowo sempat menitikkan air matanya ketika berkampanye. Ia terharu saat diberi sejumlah uang oleh seorang pendukungnya untuk membantu biaya perjuangan menjadi presiden. Pendukung tersebut bekerja sebagai montir di salah bengkel di Padang.Saat menerima sumbangan tersebut, Prabowo melepas kacamata dan menyeka air matanya."Kacamata saya ini tembus pandang, bisa melihat ketulusan hati orang," tukasnya.

Visual images yang ditampilkan pada berita ini yaitu besarnya kerumunan massa yang mengelilingi kedatangan Prabowo Subianto di bawah panasnya terik matahari. Dengan latar gambar berupa bendera partai, sejumlah massa berteduh di bawah payung, masyarakat yang mengulurkan tangan untuk bersalaman dengan Prabowo Subianto ditambah penampakan sebuah spanduk ucapan selamat datang untuk kandidat tersebut. Dalam kajian fotografi jurnalistik, pengambilan foto ini menggunakan metode medium shoot dengan sudut pandang eye level atau angle mendatar. Foto yang tidak menggunakan efek penyuntingan tersebut dipergunakan oleh Harian Padang Ekspres untuk menggambarkan keadaan yang apa adanya. Sosok Prabowo Subianto 
ditempatkan sebagai objek foto yang berada di tengah kerumunan massa. Pose tersenyum Prabowo Subianto kepada para pendukungnya diharapkan dapat menegaskan bingkai “janji” untuk kesejahteraan.

Sementara itu, dari segi perangkat penalaran berita ini menggunakan analisis kausal sebab akibat serta pemaparan klaim-klaim moral. Secara roots ada penjelasan hubungan sebab akibat yang diterangkan sebagai rakyat yang belum sejahtera, yaitu kekayaan yang mengalami kebocoran pendapatan dan dinikmati oleh segelintir orang. Kekayaan negara sebesar Rp 1.000 triliun yang mengalir ke luar negeri ditonjolkan sebagai alasan kemelaratan rakyat.Sistem ekonomi yang seharusnya berakar Pancasila, dengan nilai-nilai keadilan sosial dikatakan belum terwujud.

Perangkat penalaran berupa appeals to principle ditemukan sejumlah premis dasar yang menggambarkan klaim moral.Pembaca dibawa berfikir tentang kondisi bangsa saat ini. Salah satu cara yang ditawarkan untuk mensejahterakan masyarakat adalah dengan menekan jumlah produk impor. Hal itu ditemukan pada kutipan berikut ini:

"Selain menurunkan harga listrik dan sembako, Prabowo juga berjanji akan membuka lapangan kerja seluas-luasnya, menaikkan gaji ASN, memperbaiki gaji tenaga kerja dan guru honorer, dan tidak akan mengimpor demi menyelamatkan petani dan nelayan."

Harian Padang Ekspres juga menutup pemberitaan ini dengan ajakan untuk menjaga hak pilih di tempat pemungutan suara (TPS).Penonjolan ini sebagai sebuah konsekuensi untuk mendukung framing yang disajikan yaitu menjanjikan kesejahteraan masyarakat. Efek yang didapat dari bingkai ini adalah jika ingin mendapatkan kesejahteraan, maka harus mendukung Prabowo Subianto dengan cara memilihnya dan mengawasi proses Pemilu 2019. Hal ini dapat dilihat pada pkalimat penutup berita yang berbunyi:

"Mari tanggal 17 April 2019 kita jaga TPS.Jangan sampai ada hantu mau milih, tuyul-tuyul datang.Jangan sampai "orang mati" datang ke TPS," imbau Prabowo."

Untuk lebih jelasnya, kerangka pembingkaian berita Harian padang Ekspres edisi Kamis, 4 April 2019 dapat dilihat dari tabel berikut: 
Tabel 5.2 Pembingkaian Berita Harian Padang EkspresEdisi Kamis, 4 April 2019

\begin{tabular}{|c|c|}
\hline \multicolumn{2}{|c|}{ Frame Central : Prabowo Subianto Menjanjikan Kesejahteraan Masyarakat } \\
\hline $\begin{array}{l}\text { Framing Devices } \\
\text { (Perangkat Framing) }\end{array}$ & $\begin{array}{l}\text { Reasoning Devices } \\
\text { (Perangkat Penalaran) }\end{array}$ \\
\hline $\begin{array}{l}\text { Methapors } \\
\text { Sistem ekonomi Indonesia berasaskan } \\
\text { pancasila, namun kekayaan hanyalah } \\
\text { milik segelintir orang. Penyematan } \\
\text { gelar kaya bagi segelintir orang diikuti } \\
\text { dengan membawa kekayaan alam } \\
\text { Indonesia ke luar negeri }\end{array}$ & $\begin{array}{l}\text { Roots } \\
\text { rakyat yang belum sejahtera, } \\
\text { disebabkan bocornya kekayaan negara } \\
\text { dan dinikmati oleh segelintir orang. } \\
\text { Kekayaan negara sebesar Rp } 1.000 \\
\text { triliun yang mengalir ke luar negeri } \\
\text { ditonjolkan sebagai alasan kemelaratan } \\
\text { rakyat. }\end{array}$ \\
\hline $\begin{array}{l}\text { Catchphrases } \\
\text { Penekanan pada kalimat memberikan } \\
\text { jiwa dan raga untuk kemajuan } \\
\text { Indonesia }\end{array}$ & $\begin{array}{l}\text { Appeals to principle } \\
\text { Pembaca dibawa berfikir tentang } \\
\text { kondisi bangsa saat ini. Salah satu cara } \\
\text { yang ditawarkan } r \\
\text { mensejahterakan masyarakat adalah } \\
\text { dengan menekan jumlah produk } \\
\text { impor. }\end{array}$ \\
\hline 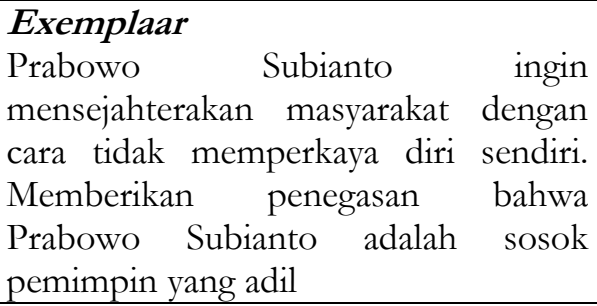 & $\begin{array}{l}\text { Consequences } \\
\text { Ajakan mengawasi proses pemilu dari } \\
\text { segala kecurangan }\end{array}$ \\
\hline $\begin{array}{l}\text { Depiction } \\
\text { Pembahasan khusus bagaimana } \\
\text { Prabowo Subianto menitikkan airmata } \\
\text { saat mendapatkan sumbangan dari para } \\
\text { pendukung }\end{array}$ & \\
\hline $\begin{array}{l}\text { Visual Images } \\
\text { Besarnya kerumunan massa yang } \\
\text { mengelilingi kedatangan Prabowo } \\
\text { Subianto di bawah panasnya terik } \\
\text { matahari. }\end{array}$ & \\
\hline
\end{tabular}




\section{Pembingkaian Berita Harian Padang Ekspres Edisi Senin, 8 April 2019}

Harian Padang Ekespres memberi judul headline pada edisi Senin, 8 April 2019 dengan "Prabowo Tegaskan Janji Perubahan". Sementara Sub Judul yang ditonjolkan adalah Kampanye Akbar, Massa Menginap di SUGBK serta Paslon 01 Siap Hadirkan Lebih Banyak Pendukung.Ide sentral pembingkaian berita ini adalah Prabowo Subianto menawarkan perubahan.

Berita ini menggunakan perangkat framing dengan menekankan perumpamaan (metafora) dengan klaim bahwa kampanye yang digelar di kawasan Stadion Utama Gelora Bung Karno (SUGBK) adalah yang terbesar sepanjang sejarah.Prabowo Subianto mulai digambarkan dengan agen perubahan yang seolah mampu mengukir sejarah baru. Ramainya massa yang hadir dalam suatu iven kampanye politik tersebut diistilahkan dengan "lautan manusia". Hal itu dapat dijumpai pada kalimat berikut ini:

"Lautan manusia memenuhi Stadion Utama Gelora Bung Karno (SUGBK), Senayan, Jakarta, saat pasangan Prabowo Subianto dan Sandiaga Salahuddin Uno menggelar kampanye akbar kemarin (7/4)... Mereka datang dari berbagai daerah demi mempersiapkan kampanye yang disebut-sebut memiliki massa terbanyak itu... Dalam orasinya, Prabowo menyampaikan apresiasi atas dukungan para simpatisan maupun relawan yang memenuhi SUGBK sejak malam.Prabowo menilai kampanye di SUGBK kemarin sebagai rapat politik terbesar sepanjang sejarah."

Selain metafora, perangkat framing lainnya yang dapat dijumpai pada berita ini adanya penonjolan kalimat (depiction) berupa "rakyat menginginkan perbaikan". Bahkan secara spesifik kalimat yang digunakan mengutip langsung pernyataan kandidat seperti berikut:

"Rakyat sudah tidak mau dibohongi, sudah muak dengan korupsi, ketidakadilan, tidak mau haknya diinjak-injak," tegas mantan Danjen Kopassus itu."

Berita ini juga menampilkan jargon yang cukup menonjol (catchphrases) yaitu negara sedang sakit dan ibu pertiwi sedang diperkosa. Perangkat ini dimaksudkan untuk mendorong pembaca mengetahui perubahan seperti apa yang paling urgent untuk diprioritaskan. Sakit identik dengan darurat dan obat.Setiap penyakit sejatinya harus segera dicarikan obat agar tidak makin membahayakan jiwa. Kutipan yang dipetik langsung adalah sebagai berikut:

"Saya berdiri di sini karena berpandangan negara sedang sakit.Ibu pertiwi sedang diperkosa karena kekayaan negara kita diambil terus," cetus dia."

Pada bagian perangkat framing berupa uraian yang memperjelas bingkai(exemplaar) ditemukan kalimat yang mendasari Prabowo dan Sandiaga untuk maju sebagai kandidat yaitu semangat untuk bekerja dan berbakti. Seperti pada kutipan berikut ini: 
"Keinginannya untuk maju bersama Sandi, kata Prabowo, tidak lain didasari semangat untuk bekerja dan berbakti. Rakyat, menurut dia, sudah tidak sabar menginginkan perubahan, ingin kekayaan negara kembali.Termasuk pula komitmen dan janji untuk menciptakan pekerjaan bagi masyarakat."Kami akan bikin pekerjaan, bukan hanya kartu-kartu," ujarnya."

Sementara itu, visualimages yang ditampilkan cukup menggambarkan suasana kampanye yang ramai dihadiri massa. Kedua kandidat ditampilkan secara bersamaan. Di sebelah kiri, terpajang foto Prabowo Subianto yang sedang berorasi di kawasan GBK dikelilingi lautan manusia, sedangkan di samping kanannya ada foto Jokowi-Maruf Amin melambaikan tangan dari atas kereta kuda dengan pengawalan ketat paspampres di kawasan Tanggerang, Banten.

Foto Prabowo Subianto sebagai calon penantang disandingkan dengan kandidat petahana Jokowi yang dikawal pasukan pengamanan, juga dapat ditafsirkan untuk menguatkan ide central framing ini, yaitu perubahan yang dijanjikan.Foto ini mengandung makna, Prabowo diharapkan menjadi pembawa perubahan atas pemimpin yang sedang berkuasa.

Dari segi perangkat penalaran (reasoningdevices) berita ini ingin menyampaikan pesan bahwa negara sedang melarat karena masalah ekonomi.Roots yang diselipkan pada berita adalah pemerintahan yang tidak berpihak pada rakyat dan pemimpin yang tidak mencarikan solusi terbaik.Karena itu sosok kandidat Prabowo disebutkan telah mempersiapkan pakar-pakar di setiap bidang. Hal ini dapat dilihat pada kutipan berita seperti berikut:

"Pakar-pakar itu bertugas mencari solusi atas masalah yang membuat masyarakat susah. Prabowo juga memastikan akan ada perubahan cepat jika memenangi pilpres tahun ini. "Saya tanya Bang Rizal Ramli, bisa gak turunkan tarif listrik. Bayangan saya itu butuh 1,5 tahun. Tapi, hitungan beliau bisa 100 hari pertama," ungkapnya."

Sementara itu premis dasar maupun klaim moral (appeal to principles) yang disuguhkan adalah adanya temuan lapangan oleh para kandidat saat berkampanye di sejumlah daerah.Disebutkan bahwa masyarakat tidak puas dengan kepemimpinan rezim yang sedang berkuasa. Hal itu dapat dijumpai pada kutipan berikut:

"Sandi di tempat yang sama menambahkan, perjalanannya ke lebih dari 1.500 titik di daerah menunjukkan aura keinginan perubahan.Pasalnya, saat ini masyarakat terbebani tarif listrik yang tinggi dan lapangan pekerjaan yang sulit.Di saat panen, petani malah rugi karena harga panen mereka anjlok akibat produk impor yang menyaingi. "Prabowo-Sandi akan menyelesaikan masalah ekonomi kita. Ayo siap bergerak 17 April," ajaknya." 
Dari uraian di atas, juga terselip efek yang didapat dari bingkai (consequences) yaitu Prabowo dan Sandiaga Uno adalah pasangan kandidat yang akan menyelesaikan permasalahan ekonomi bangsa Indonesia. Di sisi lain, meskipun secara umum pembingkaian berita ini lebih menonjolkan sosok Prabowo Subianto dan Sandiaga Uno dengan bingkai menawarkan perubahan, Harian Padang Ekspres juga tetap menyelipkan kalimat pembanding sebagai unsur keberimbangan berita. Hal itu seperti digambarkan sebagai berikut:

"Sementara itu, paslon 01 bakal menggelar kampanye akbar di GBK pada 13 April atau sebelum memasuki masa tenang. Kampanye terakhir itu bertajuk "Konser Putih Bersatu Menuju Kemenangan Indonesia Maju. Menurut dia, kampanye paslon 02 biasa saja dan tidak ada yang istimewa."Tunggu 13 April nanti," ujar Ma'ruf."Pesta itu harus senang.Pesta itu harus gembira.Jangan sampai dengan adanya pesta demokrasi, diciptakan ketakutan-ketakutan.Jangan sampai dengan adanya kegembiraan pesta demokrasi justru marah-marah," ucapnya."

Untuk lebih jelas mengenai pembingkaian berita Harian Padang Ekspres edisi Senin, 8 April 2019 dapat dilihat dari tabel berikut ini:

Tabel 5.3 Pembingkaian berita Harian Padang Ekspres edisi Senin, 8 April 2019

\begin{tabular}{|l|l|}
\hline \multicolumn{2}{|c|}{ Frame Central : Prabowo Subianto Menawarkan Perubahan } \\
\hline $\begin{array}{l}\text { Framing Devices } \\
\text { (Perangkat Framing) }\end{array}$ & $\begin{array}{l}\text { Reasoning Devices } \\
\text { (Perangkat Penalaran) }\end{array}$ \\
\hline $\begin{array}{l}\text { Methapors Subianto digambarkan } \\
\text { Prabowo prabowo telah mempersiapkan pakar- } \\
\text { dengan agen perubahan yang seolah } \\
\text { mampu mengukir sejarah baru. } \\
\text { Ramainya massa yang hadir dalam } \\
\text { suatu iven kampanye politik tersebut } \\
\text { diistilahkan dengan "lautan manusia". }\end{array}$ & $\begin{array}{l}\text { Roots } \\
\text { bertugas mencari solusi atas masalah } \\
\text { yang membuat masyarakat susah }\end{array}$ \\
\hline $\begin{array}{l}\text { Catchphrases } \\
\text { Menononjolkan kondisi negara sedang } \\
\text { sakit dan ibu pertiwi sedang diperkosa. } \\
\text { Perangkat ini dimaksudkan untuk } \\
\text { mendorong pembaca mengetahui } \\
\text { perubahan seperti apa yang paling } \\
\text { urgent untuk diprioritaskan }\end{array}$ & $\begin{array}{l}\text { Appeals to principle } \\
\text { daerah menunjukkan aura keinginan } \\
\text { perubahan }\end{array}$ \\
\hline $\begin{array}{l}\text { Exemplaar lan } \\
\text { Alasan Prabowo dan Sandiaga maju }\end{array}$ & $\begin{array}{l}\text { Consequences } \\
\text { Efek yang didapat dari bingkai yaitu }\end{array}$ \\
\hline
\end{tabular}




\begin{tabular}{|l|l|}
\hline $\begin{array}{l}\text { sebagai kandidat yaitu semangat untuk } \\
\text { bekerja dan berbakti pada negara }\end{array}$ & $\begin{array}{l}\text { Prabowo-Sandi akan menyelesaikan } \\
\text { masalah ekonomi }\end{array}$ \\
\hline $\begin{array}{l}\text { Depiction } \\
\text { rakyat menginginkan perbaikan }\end{array}$ & \\
\hline $\begin{array}{l}\text { Visual Images } \\
\text { Ada foto yang menggambarkan } \\
\text { suasana kampanye yang ramai dihadiri } \\
\text { massa. Foto Prabowo Subianto sebagai } \\
\text { calon penantang disandingkan dengan } \\
\text { kandidat petahana Jokowi yang dikawal } \\
\text { pasukan pengamanan. }\end{array}$ & \\
\hline
\end{tabular}

\section{Pembingkaian Berita Harian Padang Ekspres Edisi Rabu, 10 April 2019}

Harian Padang Ekspres memberi judul beadline pada edisi Rabu, 10 April 2019 dengan "Pendukung Yakin Jokowi Menang di Sumbar". Sementara Sub Judul yang ditonjolkan adalah Target Suara di Pilpres lebih 50 Persen. Ide sentral pembingkaian berita ini adalah besarnya dukungan massa membawa optimisme Jokowi menang di Sumbar.

Dari segi perangkat framing (framing devices) pemberitaan Harian Padang Ekspres ini menghadirkan perumpamaan (metafora) yaitu "dibanjiri massa" dan "kampanye berlangsung meriah" sebagai penyampaian pesan besarnya dukungan tersebut. Metafora ini ditampilkan pada lead berita seperti berikut:

"Kampanye akbar pasangan Calon Presiden dan Calon Wakil Presiden nomor urut 01 Joko Widodo dan Ma'ruf Amin dibanjiri massa di kawasan Danau Cimpago, Pantai Padang, Selasa (9/4). Meski Jokowi dan Ma'ruf tidak hadir, tapi kampanye berlangsung meriah.Apalagi massa yang hadir dihibur oleh grup band papan atas, Slank."

Kemudian jargon dan slogan yang dipaparkan (catchphrases) antara lain adalah meningkatkan kesejahteraan yang merata bagi seluruh rakyat Indonesia tidak cukup dalam waktu lima tahun, sehingga perlu tambahan waktu lima tahun lagi. Jargon ini seringkali dipakai oleh kandidat petahana untuk dapat terpilih lagi pada periode kedua kepemimpinannya. Jargon itu disampaikan pada kutipan langsung narasumber Wakil Menteri ESDM, Archandra Tahar seperti berikut:

"...seluruh kekayaan alam Indonesia haruslah dikelola oleh warga negara Indonesia. Kekayaan alam kita harus dikelola oleh putra-putri terbaik bangsa.Dan teknologi pun harus ditingkatkan.Untuk itu, tidak cukup waktu 5 tahun bagi pemerintah saat ini.Maka, berikanlah waktu 5 tahun lagi untuk Jokowi-Ma'ruf mewujudkan itu semua," ungkap tokoh nasional asal Sumbar itu." 
Untuk mendukung ide sentral besarnya dukungan massa membawa optimisme Jokowi menang di Sumbar, diperlukan perangkat pembingkaian yang disertai dengan contoh (exemplaar) yang menguatkan. Pada berita ini, Harian Padang Ekspres mencontohkan hadirnya orang-orang penting dari kalangan elit pasangan calon Jokowi-Maruf Amin ke Sumbar. Contoh ini diperkuat lagi dengan menyebutkan satu persatu nama para kepala daerah yang hadir pada acara kampanye tersebut. Total ada 11 nama kepala daerah di Sumbar yang dirincikan penyebutan nama dan jabatannya. Ditambah lagi ada delapan nama dari kalangan tim sukse dan relawan. Bahkan pada bagian penutup berita, sengaja ditampilkan sub judul besarnya jumlah massa yang datang dari berbagai daerah ke Kota Padang untuk menyaksikan acara kampanye.

Perangkatframing selanjutnya adalah adanya kalimat yang dipergunakan untuk melabeli sesuatu (depiction) yaitu Jokowi tidak pernah lupa dengan Sumbar. Meskipun tidak bisa hadir berkampanye secara langsung, tapi Jokowi disebutkan memberikan amanat khusus kepada tim suksesnya agar menjadi perwakilan yang hadir. Penggunaan kalimat ini adalah bentuk penggambaran isu dengan kiasan. Jokowi tidak hadir namun massa yang ikut berkampanye tetap banyak, kehadiran tim sukses tetao mendapat sambutan dari massa tersebut. Artinya, Harian Padang Ekespres ingin menunjukkan kepada pembaca bahwa dukungan masyarakat tetap besar kepada calon nomor urut 01 tersebut. Hal itu dapat ditemui dalam kutipan berikut ini:

"Tim TKN Rokhimin Dahuri menyampaikan bahwa walaupun JokowiMa'ruf tidak datang dalam kampanye di Pantai Cimpago Padang, namun hal tersebut tidak menyurutkan para simpatisan dan massa pendukung menghadiri kampanye ini. "Saya diamanatkan langsung oleh Pak Jokowi untuk menghadiri kampanye akbar di Pantai Cimpago Padang. Beliau tidak pernah lupa dengan masyarakat Sumbar," jelasnya saat berorasi."

Selanjutnya, pemberitaan ini didukung juga oleh visual images berupa foto jurnalistik yang menampilkan suasana panggung konser dikelilingi oleh massa kampanye, lengkap dengan atribut bendera partai politik.

Dari sisi perangkat penalaran (reasoning devices) pembingkaian berita lebih banyak menyajikan paragraf berisi ajakan-ajakan untuk memilih Jokowi-Maruf Amin dengan sejumlah sebab. Maka dari itu, roots yang disuguhkan lebih banyak dari sisi kebijakan-kebijakan calon petahana untuk Sumatera Barat selama periode pertama kepemimpinannya. Misalnya disebutkan keberhasilan Jokowi menurunkan angka kemiskinan, anggaran dana yang besar yang telah disalurkan untuk membangun Sumbar. Misalnya pada paragraf berikut ini:

"Ia menyebutkan, alasan kenapa masyarakat harus memilih paslon 01. Salah satunya, selama pemerintahan Jokowi angka kemiskinan di Indonesia turun menjadi 9,6 persen. "Di samping itu, produk domestik bruto (PDB) mencapai lebih dari USD 1 triliun merupakan pencapaian terbaik Jokowi untuk bangsa Indonesia," ungkapnya." 
Atau misalnya perangkat penalaran yang dapat ditemukan dalam paragraf berikut ini:

“Alasan kita mendukung pasangan JokowiMa'ruf adalah karena beliaulah satu-satunya presiden yang telah mengeluarkan triliunan rupiah untuk pembangunan di Provinsi Sumbar, walaupun Jokowi kalah saat Pilpres 2014," jelas Ramlan Nurmatias saat berorasi di kampanye akbar kemarin."

Selanjutnya appeals to principle yang disajikan adalah premis dasar bahwa kandidat Jokowi yang sering dituding sebagai sosok anti Islam adalah fitnah.Klaim moralnya adalah dengan menjadikan Maruf Amin sebagai pasangan calon wakil presiden, sebagai salah satu buktinya. Pembaca Harian Padang Ekspres di Sumatera Barat dengan mayoritas penduduk beragama Islam disajikan dengan pembingkaian berita besarnya dukungan massa, meskipun kandidat calon tidak hadir langsung berkampanye. Hal itu dapat ditemukan dalam kutipan berikut ini:

"...stigma dan fitnah yang menyebutkan Jokowi anti-Islam bisa terbantahkan dengan dipilihnya Cawapres KH Ma'ruf Amin. "Hal tersebut membuktikkan bahwa Jokowi cinta dan peduli dengan umat Islam," katanya."

Perangkat penalaran terakhir yaitu consequences, atau efek yang didapat dari pembingkaian berita.Pada pemberitaan ini, efek yang diharapkan terjadi adalah munculnya optimisme pembaca untuk memilih pasangan jokowi Maruf Amin sebagaimana ajakan para narasumber berita. Meskipun Jokowi tidak hadir berkampanye langsung, besarnya dukungan massa diharapkan melebihi pemilu tahun sebelumnya. Seperti didapatkan dalam kutipan berikut ini:

"Menurutnya, TKD Sumbar menargetkan suara yang akan diraih Jokowi-Ma'ruf bisa melebihi 50 persen pada Pilpres 17 April nanti. "Kita akan upayakan angka tersebut, sehingga Pak Jokowi bisa melanjutkan program yang sudah terbukti hasilnya. Kita berkomitmen memenangkan JokowiMa'ruf," ujarnya."

Untuk lebih jelas mengenai pembingkaian berita Harian Padang Ekspres edisi Rabu, 10 April 2019 dapat dilihat dari tabel berikut ini: 


\section{Tabel 5.4 Pembingkaian berita Harian Padang Ekspres edisi Rabu, 10 April 2019}

\begin{tabular}{|l|l|}
\hline \multicolumn{2}{|c|}{ Frame Central : Besarnya Dukungan Massa Membawa Optimisme Jokowi } \\
Menang di Sumbar
\end{tabular}




\section{Penutup}

William A Gamson berpendapat framing bukanlah untuk menjelaskan sikap media setuju atau tidak setuju terhadap suatu isu yang diceritakan.Framing bukan pula untuk mengungkap apakah suatu media mendukung atau tidak mendukung suatu isu dimana dalam hal ini yaitu kandidat yang diberitakan.Gamson memberikan rentang posisi dengan format bagaimana suatu berita dibingkai lalu disajikan kepada khalayak pembaca. Formulasi model William A Gamson ini menekankan sudut pandang sebuah media yang disajikan dengan cara bercerita kepada publik.

Dari empat berita yang diteliti dari media cetak Harian Padang Ekspresada perbedaan framing di setiap edisi. Untuk edisi Jumat, 18 Januari 2019 Harian Padang Ekspres berpandangan bahwa dengan keahlian yang dimiliki, kemampuan debat kandidat Capres dan Cawapres mampu memukau masyarakat. Selanjutnya pada edisi Kamis, 4 April 2019 Harian Padang Ekspres membingkai beritanya dengan menekankan orasi kampanye Prabowo Subianto tentang peningkatan kesejahteraan dan perekonomian.Pada berita ketiga, edisi Senin, 8 April 2019 Harian Padang Ekspres menekankan ide sentral tentang janji-janji Prabowo Subianto jika memenangi pemilu.Terakhir, pada edisi Rabu, 10 April 2019 Harian Padang Ekspres menekankan adanya optimisme kemenangan bagi Jokowi di Sumbar melihat besarnya pendukung yang hadir berkampanye.

Ke depan, hasil penelitian ini dapat dikembangkan lagi dengan penelitian-penelitian yang mengarah pada ideologi media massa di Sumatra Barat saat berlangsungnya sebuah pemilu, maupun saat adanya pemberitaan dari sumber-sumber politisi yang mengkritik pemerintah sebagai lawan politik mereka. Di sisi lain, penelitian ini juga terbatas pada pemberitaan menjelang berlangsungnya pemungutan suara alias hanya membahas seputar kegiatan pasangan calon presiden dan wakil presiden di masa kampanye. Oleh karena itu diperlukan pula, penelitian lanjutan yang mengangkat proses pembentukan kabinet pasca ditetapkannya pemenang pemilu. Dari sini muncul pertanyaan, bagaimana media massa melakukan pembingkaian terhadap kandidat yang kalah dalam pemilu maupun yang menang.

\section{Daftar Pustaka}

Abrar, Ana Nadhya. Konspirasi Media Lewat Berita. Semarang: Aliansi Jurnalis Independen.2001.

Afrizal. Metode Penelitian Kualitatif: Sebuah Upaya Mendukung Penggunaan Penelitian Kualitatif dalam Berbagai Disiplin Ilmu. Jakarta: PT. Raja Grafindo Persada.2014.

A.Ubaeidillah. Demokrasi, Hak Asasi Manusia, Masyarakat Madani. Jakarta: ICCE UIN. 2008.

Bungin, Burhan. Metode Penelitian Kualitatif: Aktualisasi Metodologis ke Arah Ragam Varian Kontemporer. Jakarta: PT. Raja Grafindo Persada.2001. 
Cangara, Hafied. Pengantar Ilmu Komunikasi. Jakarta : Rajawali Pers. 2008.

, Hafied. Komunikasi Politik: Konsep, Teori dan Strategi. Jakarta: PT. Raja Grafindo Persada. 2009.

Eriyanto. Analisis Framing, Kontruksi, Ideologi, dan politik Media. Yogyakarta: LKIS. 2002.

----------. Analisis Isi : Pengantar Metodologi Untuk Penelitian Ilmu. Komunikasi dan Ilmu-Ilmu Sosial Lainnya. Jakarta : Kencana Prenada. Media Group. 2011.

Ghozali, Imam. Aplikasi Analisis Multivariate Dengan Program SPSS. Semarang : Universitas Diponogoro.2007.

Kriyantono, Rachmat. Teknik Praktis Riset Komunikasi. Jakarta: Kencana Prenada Media Group.2009.

Moleong, L.J. Metodologi Penelitian Kualitatif. Bandung: Remaja Rosda Karya.2004.

Rolnicki, Tom E. Pengantar Dasar Jurnalisme (Scholastic Journalism). Jakarta: Kencana.2008.

Siahaan, Hotman M, dkk. Pers Yang Gamang: Etudi Pemberitaan Jajak Pendapat Timor Timur, Surabaya: LsPs, ISAI, USAID,. 2001.

Sobur, Alex. Analisis Teks Media : Suatu Pengantar Analisis Wacana, Analisis. Semiotika, dan Analisis Framing. Bandung : Remaja Rosdakarya.2012.

Sudibyo, Agus. Politik Media dan Pertarungan Wacana. Jogjakarta: LKIS. 2001.

Sugiyono. Memahami Penelitian Kualitatif. Bandung: Alfabeta. 2005.

- Metode Penelitian Kuantitatif Kualitatif dan E\&D. Bandung: Alfabeta. 2009.

\section{Penelitian terdahulu:}

Andika Destika Khagen. Teks Berita Calon Presiden RI Periode 2014-2019 Dalam Portal VIVA.CO.ID dan TEMPO.CO (Analisis Wacana Perspektif Teun A. van Dijk) Masters thesis, UPT. Perpustakaan Unand. 2015.

Hariyadi. Pembingkaian Berita Dalam Upaya Menjaga Citra Positif DPRD Provinsi Sumatera Barat (Analisis Framing Rubrik Majalah Mimbar Tahun 2014-2015). Masters thesis, UPT. Perpustakaan Unand.2015.

Intan Permata Sari. Jurnal Penelitian Komunikasi Vol 21, No 1 Juli 2018 Fakultas Tarbiyah dan Tadris IAIN Bengkulu. 2018.

Rully, Febriansyah. Bingkai Berita Kebijakan Publik Pemerintah Kabupaten Tabalong. (analisis framing kolom kontrak pemberitaan surat kabar regional Kalimantan Selatan tahun 2013) Masters thesis, UPT. Perpustakaan Unand.2016. 
Ricky Alkat Seftiano. Analisis Framing Pemberitaan Pemilihan Gubernur Kalimantan Timur 2013 Surat kabar Kaltim Post dan Tribun Kaltim Pada Masa Kampanye. Universitas Mulawarman: Jurnal Ilmu Komunikasi.2014.

Scheufele, Dietram. Framing As a Theory of Media Effects. The Journal of Communication. 49. 103-122.1999.

\section{Sumber internet:}

https://pemilu.tempo.co/read/594282/prabowo-hatta-menang-telak-disumatera-barat/full\&view=ok, diakses 23 Mei 2019 pukul 01.50 WIB

https://pemilu.tempo.co/read/594282/prabowo-hatta-menang-telak-disumatera-barat/full\&view=ok, diakses 23 Mei 2019 pukul 01.54 WIB

https://www.dw.com/id/koalisi-prabowo-akhirnya-kuasai-mpr-dan-dpr/a17982335. diakses 19 Mei 2019 pukul 08.10 WIB

https://aji.or.id/read/press-release/284/Siaran-Pers-Hentikan-Praktik-

Jurnalisme-Partisan.html diakses 19 Mei 2019 pukul 16.00 WIB

https://dewanpers.or.id/publikasi/siaranpers_detail/117/Siaran_Pers:_Dewan_ Pers_Sampaikan_Peringatan_Etik diakses 19 Mei 2019 pukul 17.00 WIB

https:/ / tirto.id/ramai-ramai-pemilik-media-merapat-ke-jokowi-buruk-untukdemokrasi-cXMH diakses 19 Mei 2019 pukul 15.30 WIB.

https://pemilu.antaranews.com/berita/866734/kpu-sumatera-baratrampungkan-rekapitulasi-suara-pemilu-2019, diakses 23 Mei 2019

\section{Sumber lain:}

Company Profile PT Padang Intermedia Group (2019) 